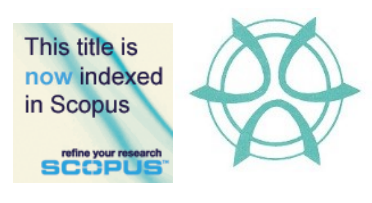

PLANNING MALAYSIA:

Journal of the Malaysian Institute of Planners

VOLUME 18 ISSUE 3 (2020), Page 51 - 70

\title{
THE ENTITY - IDENTITY RELATIONSHIPS OF OLD SHOP HOUSES IN PERAK THROUGH FACADE DESIGN
}

\author{
Mohd Jaki Mamat ${ }^{1}$ \& Muhammad Firzan Abdul Aziz ${ }^{2}$ \\ ${ }^{1,2}$ School of Housing, Building and Planning \\ UNIVERSITI SAINS MALAYSIA
}

\begin{abstract}
Since the 19th century, old shop houses remaining in Malaysia have been a primary indicator of the country's physical landscape which can inform significant historical background of early cities and towns. The old shop houses testify in the uniqueness and diversity of the nation's architectural gems, which were shaped by the Malay, Chinese and British entities. The current study attempts to understand the influence of varying entities towards the architectural identities that the old shop houses' facade bear. Purposive sampling of 16 towns in the state of Perak was made to gauge information on the earliest row of shop houses at each of the towns. Both secondary and primary data were then leveraged based on documents analysis, interviews and measured drawings to explore the relationship link between the entities and identities through the old shop houses' facade design. The findings suggest that there is a relationship between the entities and identities, in the sense that the early entities were influential in determining the identities of the old shop houses' facade design. Interestingly, the Malay style was found to be the most dominant identity depicted by the facade design of the old shophouses from the 16 towns of Perak.
\end{abstract}

Keywords: Shophouses, facade, entity \& identity

\footnotetext{
${ }^{1}$ Corresponding author's email: mohdjaki@usm.my
} 
Mohd Jaki Mamat ${ }^{1}$ \& Muhammad Firzan Abdul Aziz

The Entity - Identity Relationships of Old Shop Houses in Perak Through Facade Design

\section{INTRODUCTION}

Construction project is not simply restricted to the new buildings only but it also includes restoration and maintenance of existing building. Heritage can be one of the whys and wherefores. The National Heritage Department (2016) defined heritage as a valuable inheritance that can be categorized under tangible and intangible components.

A construction project can be considered successful or not through project management triangle; time, cost and quality. Roy and Kalidindi (2017) has unfortunately reported that for conservation project, the performance in terms of time, quality and especially cost is far from satisfactory. Bowen et al. (2002) claimed that neglecting any one factor would affect other two factors. This shows that factor of cost for conservation project is important to be highlighted in order to prevent delay and low quality of the conservation project. Currently, the industry is facing several issues that have caused cost and time overruns and also contractual disputes during post-contract stage (Lee \& Lim, 2010; Hisham \& Hassan, 2015). Surprisingly there are actually many countries facing the same difficulties when dealing with heritage building. Roy and Kalidindi (2017) said that Canada, Italy, Australia and India are some of the countries that reported frequent failures in meeting the delivery goals of time, quality, scope and budget.

One of the factors of failing to reach the budget of conservation project is because of limited research on costing aspect of conservation project (Hisham \& Hassan, 2015; Wee \& Lim, 2010). Kamal et al. as cited in Wee and Lim (2010) explained reason for limited research on costing aspect of conservation works is because building conservation practice in Malaysia is relatively new compared to some other countries. This is supported by Lim (2017) where he claimed that conservation processes may be broadly studied by researcher, however, the same cannot be said for the cost management aspect, namely cost control, cost budgeting and cost estimating. This shows that more research on costing of conservation project must be performed so that issues on cost overrun that often occur in the project can be successfully prevented and solved.

During the 19th century, shophouses were the dominant architectural feature that can be seen in the early major cities and townships of Malaysia. Apparently, most of the shop house buildings remain intact until today (Wan Hashimah, 2015). The significance of heritage shop houses is embedded in their cultural fabric and design, which bears strong relationship with and influence from the early communities and societal groups occupying them (Nur Farhana, 2014). Despite the introduction and implementation of planning policy by the British administration at that time, the design of shop house buildings has nevertheless remained unique due to the influence of early communities and societal groups onto them (Shahrul, 2016).

The tin mining industry was central in shaping the formation of Perak's early towns and cities. In fact, the construction of shop houses has long been 
rooted to the tin mining activities by the British colonists and Chinese immigrants (Lees, 2017). This has resulted in the architectural amalgamation of the two influences, as mainly apparent in the facade design of shop house buildings. Yet so, traditional design features from the Malay architectural styles can still be seen on the shop houses, particularly at several building elements such as the roof, window and ornaments (Han, 2016).

In realising such scenario, this paper attempts to understand the entityidentity relationships of early shop houses' in Perak through the buildings' facade design. There were 16 early towns in Perak researched namely Pengkalan Hulu, Lenggong, Kuala Kurau, Kuala Sepetang (Port Weld), Padang Rengas, Manong, Tanjung Rambutan, Papan, Pusing, Klian Intan, Lumut, Malim Nawar, Chenderiang, Parit, Sungkai and Bagan Datuk. In order to analyse the entityidentity relationships, the earliest shop house building has been sampled each from the 16 localities aforementioned.

In this paper, the operational definition of entity refers to the builders and owners involved during the built year of the old shop houses. Meanwhile, identity refers to the architectural styles, design, characteristics and cultural images potrayed at the facade of the old shop houses.

\section{LITERATURE REVIEW}

\section{Construction of shop houses}

The urban morphology and building typology in Southeast Asia's landscape have much been influenced by the flourish of the trading industry during the 18th century. The earliest and grandest trading centre of Southeast Asia circa 15th century, Melaka, was an unwalled suburb divided into commercial, residential and administrative zones (Han, 2016). Back then, the typical Malay traditional built structures catering business activities were simply made of wooden walls (some were also found without the walls) and roofed (Zulkifli, 2012; Siti, 2014). However, Melaka was later divided merely into commercial and administrative zones (resided by European officials and merchants) upon the conquest by the Dutch from the Portuguese in 1641. Consequently, multi-function premises that combine residential and business purposes were built by the Dutch colonists within the fort of Melaka. Although the premises were scattered in position, this event is significantly believed to be the starting point of shop house construction therein (Han, 2016). Moreover, there is no evidence found in attributing the construction of business premises with the Chinese traders in spite of their early arrival in Melaka prior to the Portuguese take over in 1511.

By the 18th century, emergence of Melaka as an international trading port has resulted in the rapid construction of shop houses, which were mainly owned by the Chinese traders. The Dutch's policy in segregating settlement zones based on races has apparently influenced the merging of residential and commercial purposes within a premise. The rapid urban development occurred 
Mohd Jaki Mamat ${ }^{1}$ \& Muhammad Firzan Abdul Aziz

The Entity - Identity Relationships of Old Shop Houses in Perak Through Facade Design

has also influenced the positioning of the shop house buildings, arranged in long rows with multi-layers, similar to the grid system that is common for town planning (Han, 2016; Mohd Jaki, 2018). The residential cum commercial premises can also be found in Indonesia, which nation was historically under the Dutch's ruling (Rizal, 2017).

Shop houses are built to fulfil commercial purposes. In this sense, its construction plays a vital role in the economic and morphological developments of a locality (Shahrul, 2016; Mohd Jaki, 2018). By characteristics, shop house buildings combined both residential and commercial functions. Shop houses can be found to exist in the early development of almost all historic commercial cities in Malaysia especially in Melaka and Penang (Han, 2016). In Perak's case, construction of shop houses became rampant upon the British's arrival in the 19th century, in conjunction with the existence of main cities such as Ipoh, Taiping and Teluk Intan (Mohd Jaki, 2018). Theoretically, the shop houses were built by the Chinese immigrants to carry on their business activities (Rashiwala, 2018). In turn, such constructions have affected the physical landscape of major cities and towns that remain until today (Nur Farhana, 2014; Rashiwala, 2018).

\section{Shop houses' facade design}

Exploring and studying Malaysian heritage sites are imperative to deepen the understanding of physical features of the past, in particular from the Malay sultanate to the colonialist's eras (Shahrul, 2016). It is apparent that most facade designs of Malaysian shop houses were influenced by the Chinese in the 19th century, the British in the 20th century as well as the two combinations. Built materials used meanwhile were mostly resourced locally. The British was influential to the design of shop houses in major cities as they were involved in appointing and recognising their native architects. On the other hand, the locals being involved were merely craftsmen and master-builders whose scopes were limited to drafting plans- hence the diminished indigenous features in the shop houses design (Tan, 2014). Nevertheless, shop houses which design adapts the traditional Malay architecture style can still be found, using common building elements and local materials (Han, 2016).

Although climate is a crucial factor in architecture, it can be observed that building elements of the shop houses such as doors, windows, wind lattices and gable ends were much influenced by the local culture and ethnicities (Omar, 2011). Shop houses were also designed to cater business activities in the sense of having a facade with wide openings and having a five-foot way (Nurlisa, 2015; Harding, 2018). It is important to note that the five-foot way is an important design feature of shop houses' facade, believed to be originated from the Dutch's commercial premise and those of southern China specifically brought by the immigrants from Fujian and Guangzhou (Harding, 2018). 
The facade design of Malaysian old shop houses generally were maneuvered to respond to the commercial activities intended. Other relevant factors that have contributed to their design characteristics include shape and form, built material, colour and texture, decorative ornament and embellishment as well as scale and proportion (Mostafa, 2018). In addition, existence of linear rows of shop houses with road systems in between can be associated with the urban morphology factor which is typically based on linear and grid planning systems (Taylor, 2010; Mohd Jaki, 2018).

\section{The entity-identity relationship through facade design}

In the realm of the built environment, there is a significant link found between certain ethnicities and their visual preferences. Historically, each era has shown particular adaptation of functional and aesthetical characteristics into their very design (Dheyaa, 2018). Such characteristics signify the impact of human creativity towards design, driven by cultural influence (Dobson, 2012; Wan Hashimah, 2015). Such characteristics then generated local identities, which are unique due to varying climatic, geographical and cultural factors. In turn, identities created became common trends which then adapted to architectural design. Architectural identities are imperative in indicating the wisdom and progression of local people within a locality (Rizal, 2017; Noorfadhilah, 2012; Norsidah, 2012). Architectural identities are arguably more dominant than physical characteristics especially when it comes to building of heritage values (Wan Hashimah, 2015).

Besides the local communities, the immigrants and colonialists were also influential in shaping the identity of a place. Implying from that, the builders involved during the construction phase were considerably the key person in influencing the architectural design and building characteristics (Rizal, 2017). The British, in this sense, was highly influential in the local architectural scene (which include the shop houses style) in relation to the Portuguese (no influence towards shop house design found) and the Dutch colonists (merely influential to certain areas in Melaka) (Noorfadhilah, 2012). Several architectural styles such as the Moorish, Tudor, Neoclassical, Neo-Gothic etc. were actively introduced locally during the British occupation period in the 20th century (Kamaruzzaman, 2006).

Meanwhile, the influence by southern China immigrants came earlier during the 19th century which can be seen through ornamental carvings and at the uses of doors and windows that were similar to those available in China (Noorfadhilah, 2012). As a result, the indigenous image and identity brought by the Chinese immigrants then can be seen through the early shop houses design (Aidatul, 2014). They resided within their own community and carried out business activities, which led to the creation of unique architectural typology, design language or style, interior design, color scheme as well as signage. 
Mohd Jaki Mamat ${ }^{1}$ \& Muhammad Firzan Abdul Aziz

The Entity - Identity Relationships of Old Shop Houses in Perak Through Facade Design

In the case of Malay traditional architecture, it is apparent that the architectural identity was oriented towards the dominant usage of local material especially timber. Most of the main building elements, structural aspects and jointing methods were based on the use of timber. The image of Malay traditional architecture was then assimilated with the buildings built after the British arrival, as can be seen at shop houses, institutional buildings and the British officials' residences (Umi Kalsom, 2015).

Theoretically, cultural aspects are derived from certain communities (Samkin, 2010; George, 2010). In this regard, it is important to understand the genesis of shop houses identities, through the underlying entities involved in the past (Noorfadhilah, 2012). In understanding heritage sites, it is imperative to note that certain community groups are highly associated with the place they inhabited. Hence, by assessing the entity-identity relationships of the facade design of old shop houses' available within Perak's townships, the current study would further assist in the understanding of Perak's heritage at large.

\section{METHODOLOGY}

To understand the historical genesis of Perak's early shop houses, the study focused on the scope of entity-identity relationships of old shop houses in Perak. Due to limited resources available at the expense of the current researchers, this study excluded other influential aspects of architecture such as the detailed analysis of the facade elements, costing, era, technology and local knowledge. In doing so, the facade design of old shop houses during their built years were analysed by making references to secondary data available. In particular, existing records and inventories on facade design for buildings of either Malay, Chinese or British were scrutinised in line with Natthakid's (2017) method that suggests the utilisation of reliable and valid studies, writings and records to understand buildings under study. Among the key secondary sources leveraged in this study include:

1. A handbook of Features \& Materials - Penang Shophouses by Tan Yeow Wooi (2015);

2. Pemeliharaan Rupa Bandar - Panduan Mengenali Warisan Rupa Bandar berasaskan inventori bangunan warisan di Malaysia by Syed Zainol Abidin Idid (1995);

3. Kutai House - Documentation of memories by Mohd Sabrizaa Abd. Rashid (2017) and;

4. Traditional Malay House of Northern Perak by Mohd Jaki Mamat (2017).

The information from those sources were then synthesised into an inventory of facade design identity as tabulated in Table 1 as well as Figure 1 to Figure 7: 
PLANNING MALAYSIA

Journal of the Malaysia Institute of Planners (2020)

Table 1; Identity of old shop houses' facade design based on the 3 main entities.

\begin{tabular}{|c|c|c|}
\hline European & Chinese & Malay \\
\hline $\begin{array}{l}\text { Bricks, Marseille roof } \\
\text { tiles, frame or architrave, } \\
\text { classical architecture (arch } \\
\text { window, key stone, } \\
\text { column order, cornice), } \\
\text { Art Deco style (coloured } \\
\text { glass, steel, clean surface, } \\
\text { geometrics line), reccess } \\
\text { panel, iron grilles. }\end{array}$ & $\begin{array}{l}\text { Bricks, U or V shape terracotta } \\
\text { roof tiles, chinese column head } \\
\text { (chi-tou), ceramic air vent, } \\
\text { granite corbel brackets, comb } \\
\text { door, stuccoworks (chinese } \\
\text { caligraphy, carving and motive), } \\
\text { gable end design, sunken panel } \\
\text { with ceramic vent tiles }\end{array}$ & $\begin{array}{l}\text { Tatched roof, timber plank } \\
\text { wall (tindih kasih), } \\
\text { decorated panel or louvre, } \\
\text { louvers window, jack roof } \\
\text { (double roof), wood } \\
\text { carving with floral motive, } \\
\text { gable ventilation (tebar } \\
\text { layar), timber corbles }\end{array}$ \\
\hline
\end{tabular}



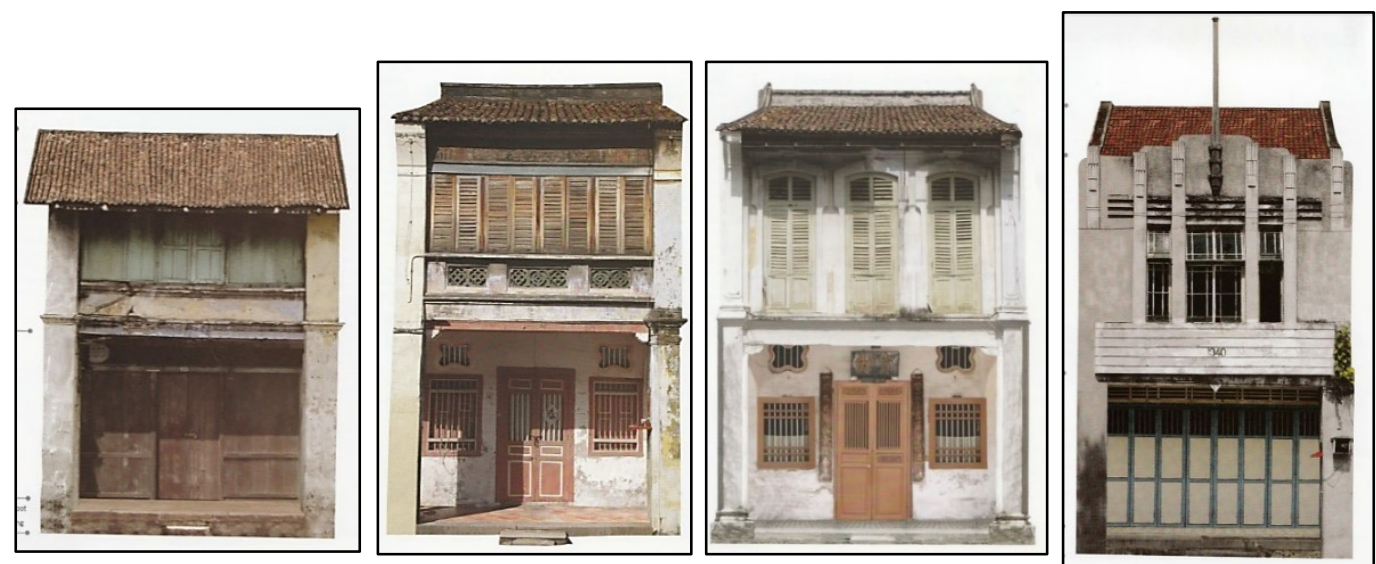

Figure 1-4, from left; Early style (1790s - 1850s), Southern Chinese Eclectic (1840s - 1910s), Straits Eclectic (1890s 1920s) \& Art Deco (1930s - early 1960s) style of shophouses (Wooi, 2015)
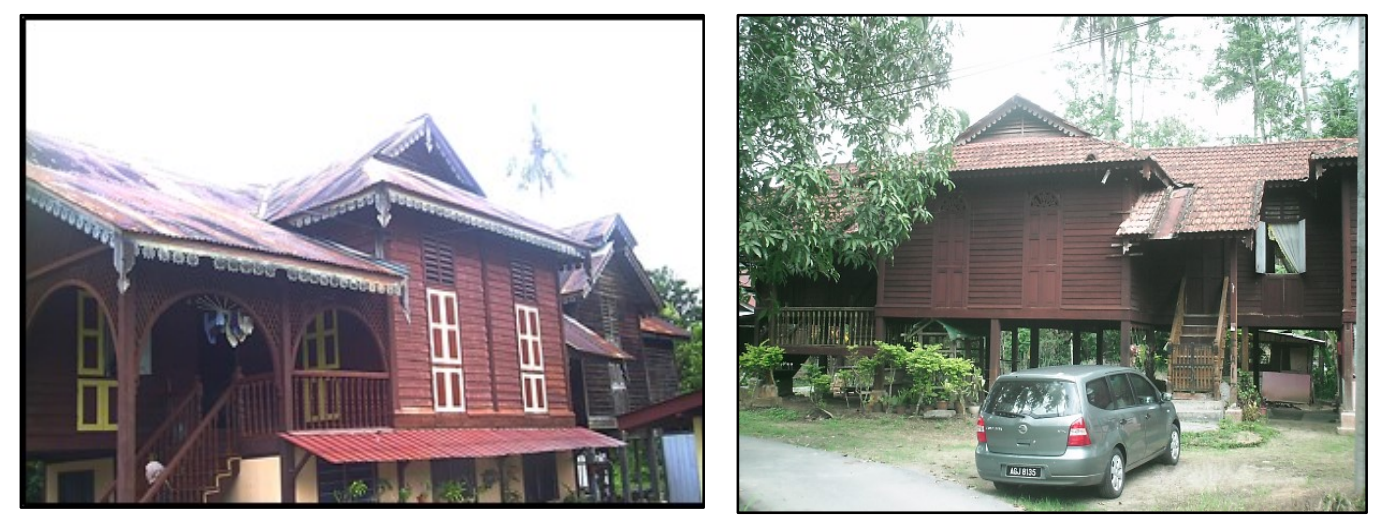

Figure 5 \& 6; Traditional Malay House in Lenggong, Perak (Mohd Jaki, 2017).

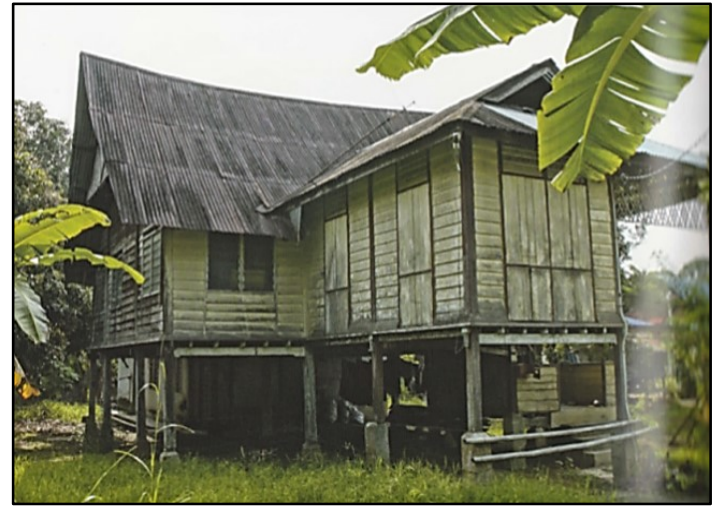

(C) 2020 by MIP
Figure 7; Traditional Malay

House (Kutai House) in Perak

(Sabrizaa, 2017) 
Based on purposive sampling, 16 towns in the state of Perak were researched namely Pengkalan Hulu, Lenggong, Kuala Kurau, Kuala Sepetang (Port Weld), Padang Rengas, Manong, Tanjung Rambutan, Papan, Pusing, Klian Intan, Lumut, Malim Nawar, Chenderiang, Parit, Sungkai and Bagan Datuk. These towns are scattered throughout the northern, central and southern regions of Perak. Interviews with the chief villagers, head communities, local historians as well as building owners and local communities were conducted to identify the earliest row of shop houses in each of the aforementioned towns. The interviews also covered topics on the shop houses' building background such as built history, original design, former use and function, construction cost etc. Reference to early manuscripts, old writings and seminal studies were also made yet such sources were sparse in quantity due to the fact that the 16 towns were not main cities of Perak hence the limited studies covered by the academia.

Primary data were then acquired upon the identification of early shop houses row from the interviews conducted. Measured drawings were done using measuring tape and laser devices. Facade sketches made on-site were then digitally redrawn with the aid of AutoCAD and Sketchup softwares to obtain technical accuracy. The measured drawing outputs were based on the original design of the shop houses. For instance, in the case where a building with masonry columns was found to be made of wooden timber previously, the latter material was used in the measured drawing output to ensure accurate representation of the building original design. Such recording is deemed to bear future importance when it comes to gauging the authenticity criterion of a building. However, there were problematic issues faced during the data collection process where some of the building elements have been heavily deteriorated to the extent of diminishing the building original characteristics, as well as, accessibility factor where some building owners in Pusing, Lumut, Kuala Kurau and Padang Rengas did not grant consent for the research to be carried out at their premises.

\begin{abstract}
ANALYSIS
During the interview sessions, none of written evidence was being provided by the interviewees to support their oral claims hence resulting in some missing information. Nevertheless, two variables managed to be completely and consistently acquired from varying interviewees namely on the builder's information and building/land ownerships. This information solidifies the relationship of entity-identity relationships of old shop houses sought through the building facade design, by informing whether there is direct, indirect or no relationship between the two aspects. The inventory made is tabulated in Table 2.
\end{abstract}


Mohd Jaki Mamat ${ }^{1}$ \& Muhammad Firzan Abdul Aziz

The Entity - Identity Relationships of Old Shop Houses in Perak Through Facade Design

Table 2; Inventory of old shop houses' facade design in 16 small towns of Perak

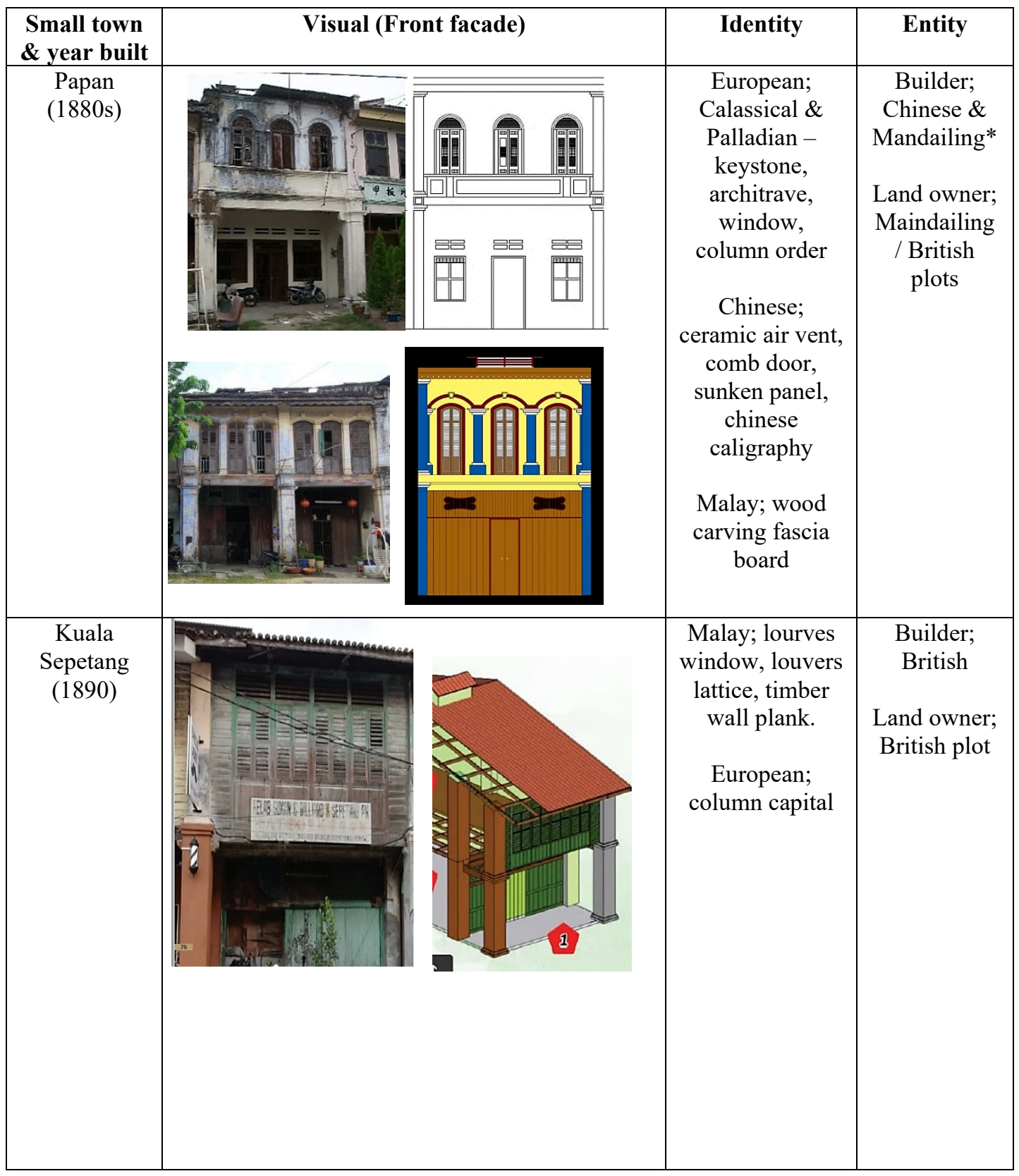


PLANNING MALAYSIA

Journal of the Malaysia Institute of Planners (2020)

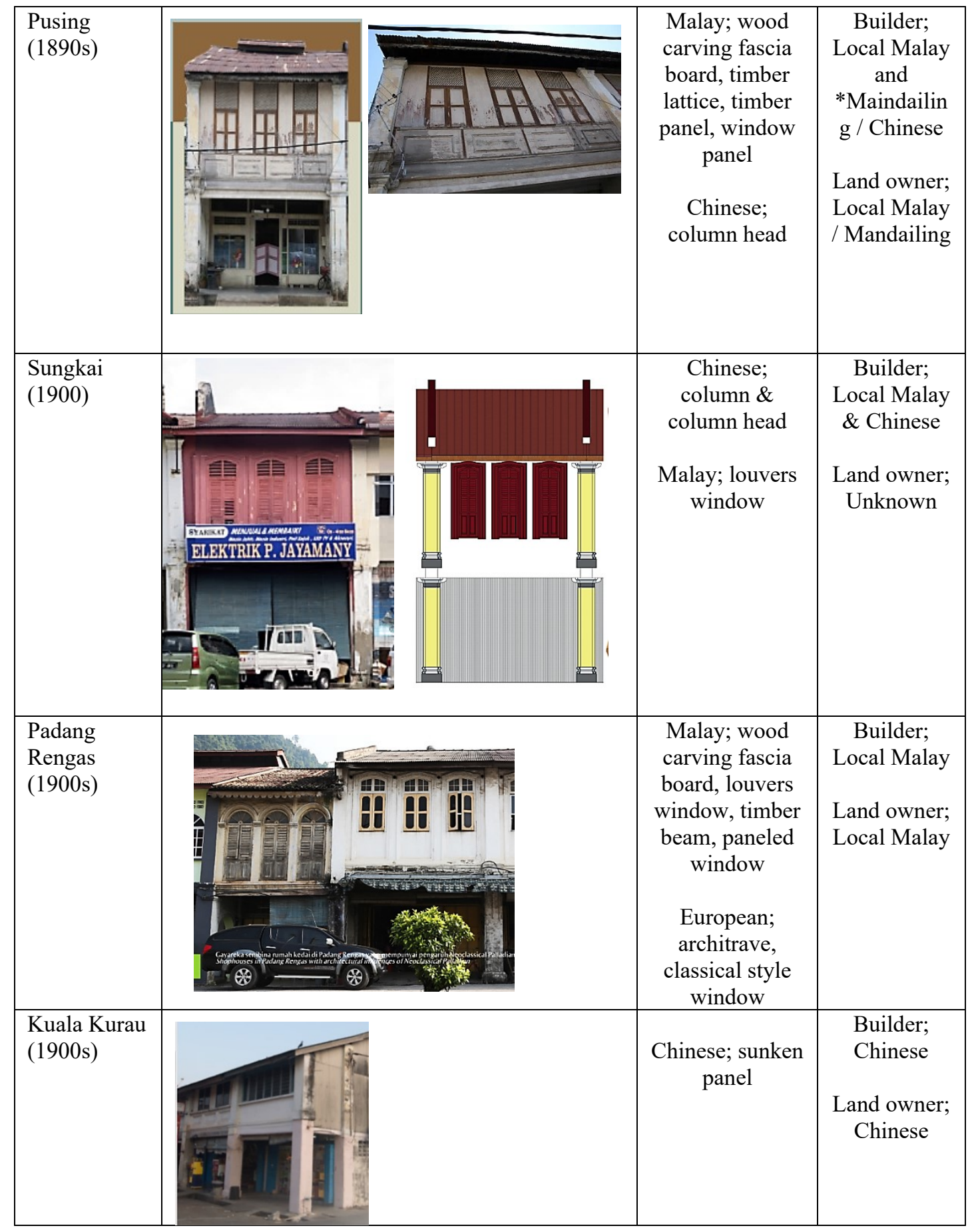


Mohd Jaki Mamat ${ }^{1}$ \& Muhammad Firzan Abdul Aziz

The Entity - Identity Relationships of Old Shop Houses in Perak Through Facade Design

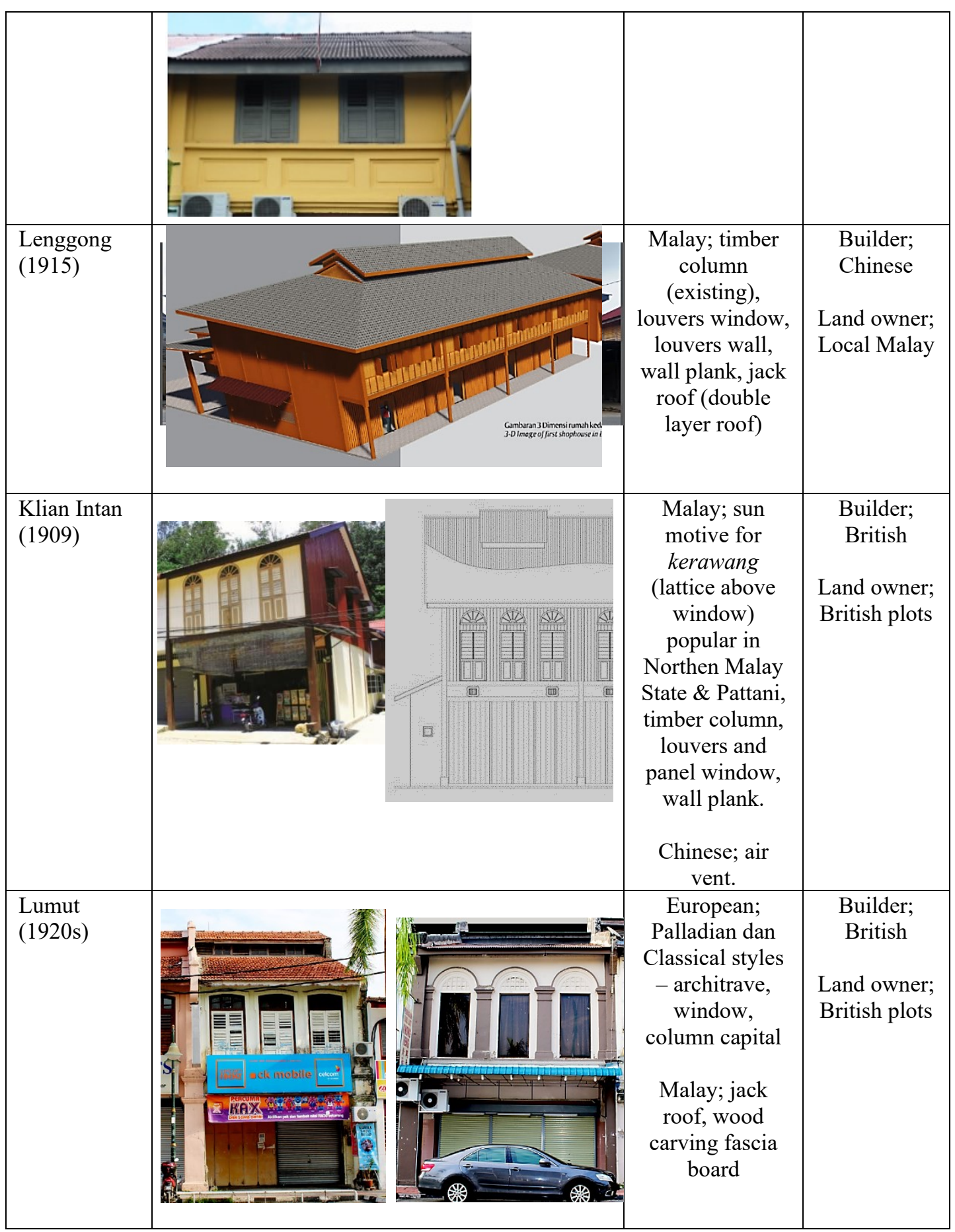


PLANNING MALAYSIA

Journal of the Malaysia Institute of Planners (2020)

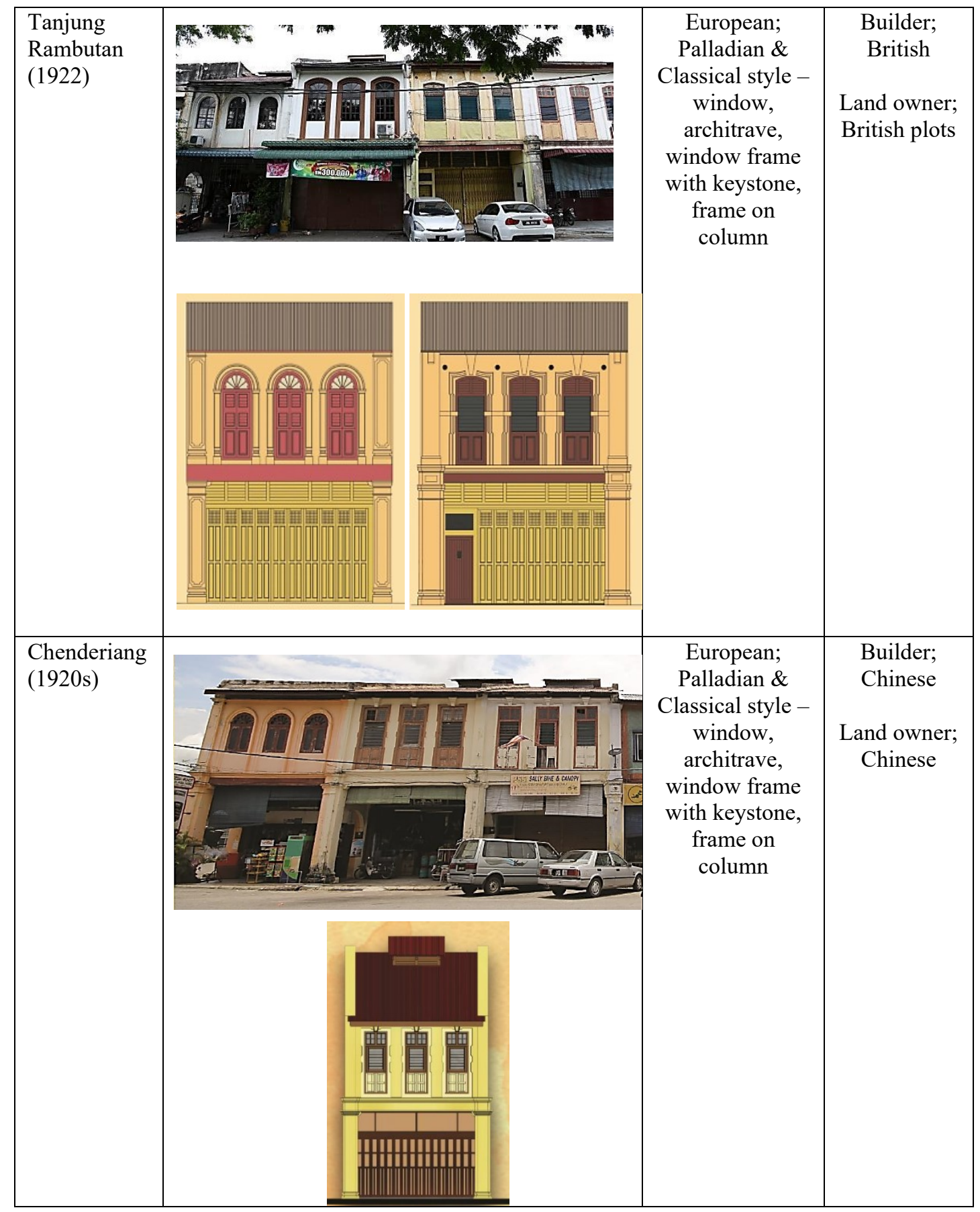


Mohd Jaki Mamat ${ }^{1}$ \& Muhammad Firzan Abdul Aziz

The Entity - Identity Relationships of Old Shop Houses in Perak Through Facade Design

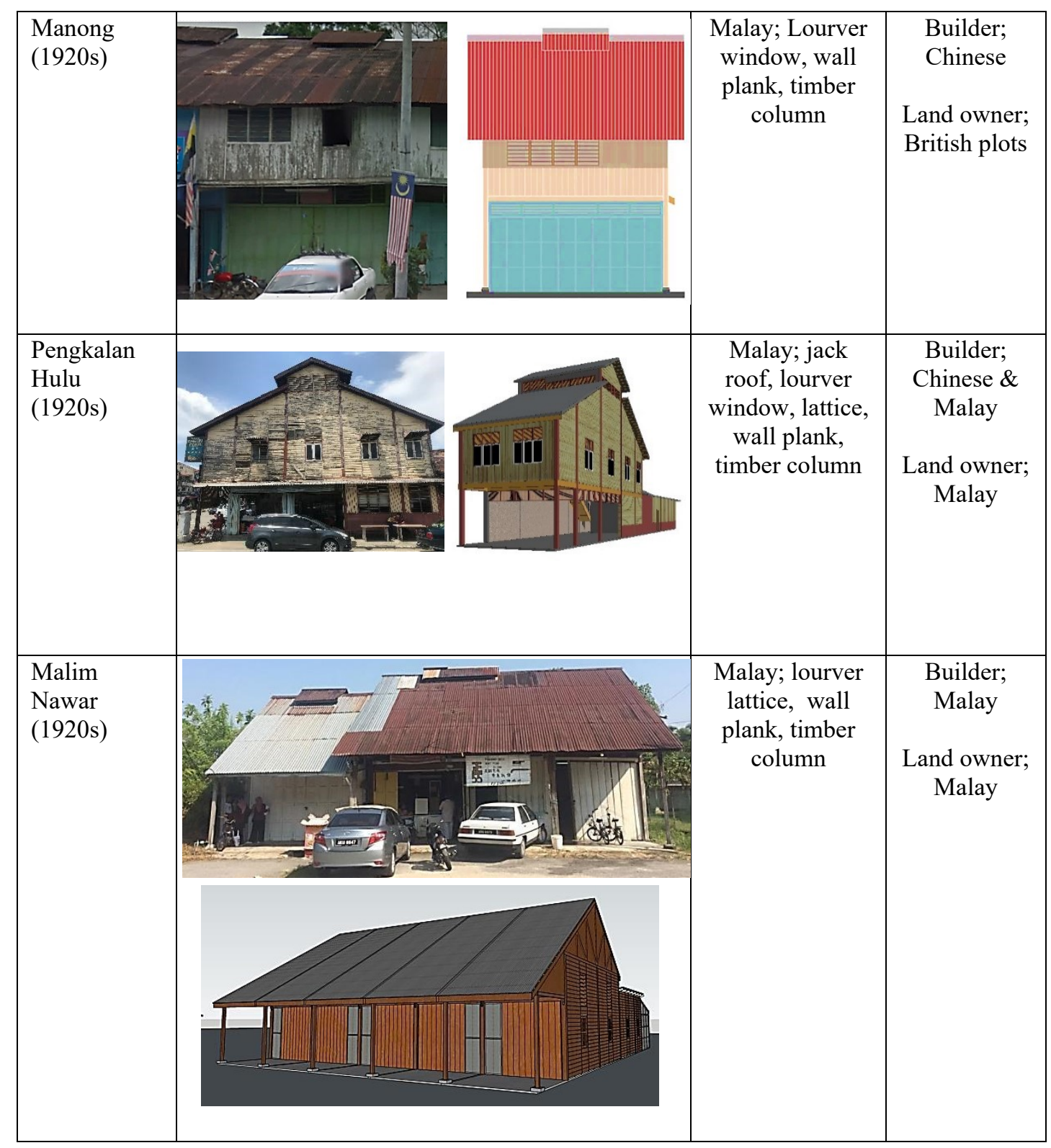


PLANNING MALAYSIA

Journal of the Malaysia Institute of Planners (2020)

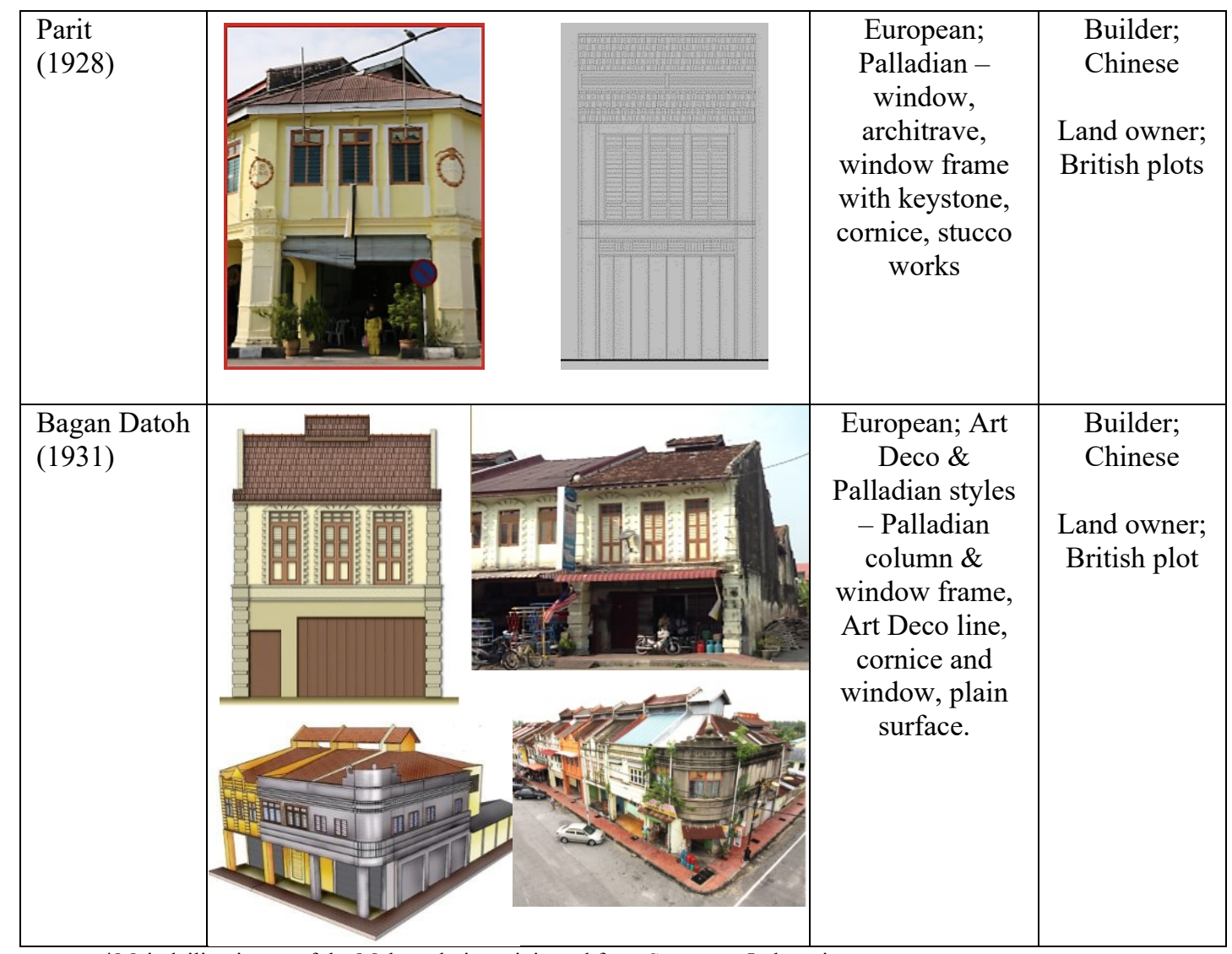

*Maindailing is one of the Malay ethnics originated from Sumatera, Indonesia.

Table 2 are indications that the Malay identity is the most influential as reflected by the shop houses' facade design from the 10 out of the 16 towns being studied. The architectural characteristics of the Malays traditional style were adopted to the entire shop houses where the Malays were either builders or owners back then. It is obvious that at Malim Nawar and Pusing, the shop houses' facade design was totally reflecting traditional Malay identity due to the ownership and construction by the Malays. However, despite having a similar historical scenario with the two towns, shop houses' facade at Padang Rengas showed the existence of European architectural influences, although they were not really dominant. This can be associated with the location of Padang Rengas (which is in close proximity about $12 \mathrm{~km}$ ) to Kuala Kangsar, which is a royal town that possesses numerous buildings built by the British.

For the cases of towns where shop houses were built by the Malay and Chinese entities, it was found that the Malay identity was fully dominant in regard to the facade design at Pengkalan Hulu and Lenggong. Merely Sungkai was found 
Mohd Jaki Mamat ${ }^{1}$ \& Muhammad Firzan Abdul Aziz

The Entity - Identity Relationships of Old Shop Houses in Perak Through Facade Design

to be the town in Perak that has the fusion of Malay and Chinese identities on their shop houses' facade design.

Other than that, the dominant identity found on the shop houses' facade design at Kuala Sepetang was the Malay traditional style. Ironically, constructions of early shop houses at Kuala Sepetang involved the British. Meanwhile in Klian Intan, the identity found was based on the fusion of Malay and Chinese styles. In contrast, the dominant identity found at Lumut was European style with minor adaptation of the Malay characteristics. Merely Tanjung Rambutan showed the full dominance of the European style throughout their shophouses' facade design, resulting from the British involvement in building the early shop houses at the town.

In a different scenario, the existence of the British and Chinese entities at Parit and Bagan Datuk showed the dominance of European style in their old shop houses' facade design. Interestingly, this finding is not consistent in the case of Manong. Despite the British and Chinese being the main entities at Manong, its old shop houses' facade design were found to be characterising the Malay traditional style. This finding can be attributed to the rationale that the Chinese immigrants at that time were given designated land by the British to build their premises, which was located within the core of trading areas of the Malays. The Malays' business premises at Manong during that time was based on simple architecture (wall-less structure with rumbia leaves as roof) with easily sourced local materials. This inferentially has influenced the Chinese merchants to adopt the style, especially when they merely run small-scale business. Besides, Manong was not an industrial tin-mining spot that was attractive to big investors and traders, rather it was just an agricultural-based town.

Kuala Kurau and Chenderiang were found to be the towns which old shop houses were of Chinese entities. However, only the facade design of old shop houses at Kuala Kurau were found to be fully dominated with Chinese identity whereas those at Chenderiang were found to have European influence. Papan meanwhile is the only town having old shop houses that were historically linked to the three entities namely the Malay, British and Chinese. In consistent with that finding, its old shop houses' facade design showed the fusion of the three styles. Table 3 summarises the overall findings:

Table 3; Summary of the entity-identity relationships of old shop houses' facade design in 16 small towns of Perak

\begin{tabular}{clcc}
\hline No. & Town & Entity & Identity \\
\hline 1 & Malim Nawar & Malay & Malay \\
\hline 2 & Pusing & Malay & Malay \\
\hline 3 & Padang Rengas & Malay & Malay \& European \\
\hline 4 & Pengkalan Hulu & Malay \& Chinese & Malay \\
\hline 5 & Lenggong & Malay \& Chinese & Malay \\
\hline
\end{tabular}


PLANNING MALAYSIA

Journal of the Malaysia Institute of Planners (2020)

\begin{tabular}{clcc}
\hline 6 & Sungkai & Malay \& Chinese & Malay \& Chinese \\
\hline 7 & Klian Intan & British & Malay \& Chinese \\
\hline 8 & Kuala Sepetang & British & Malay \\
\hline 9 & Lumut & British & Malay \& European \\
\hline 10 & Tanjung Rambutan & British & European \\
\hline 11 & Manong & British \& Chinese & Malay \\
\hline 12 & Parit & British \& Chinese & European \\
\hline 13 & Bagan Datoh & British \& Chinese & European \\
\hline 14 & Chenderiang & Chinese & European \\
\hline 15 & Kuala Kurau & Chinese & Chinese \\
\hline 16 & Papan & British, Malay \& Chinese & $\begin{array}{c}\text { European, Malay \& } \\
\text { Chinese }\end{array}$ \\
& & & \\
\hline
\end{tabular}

\section{FINDINGS}

The current study suggests that there is a direct relationship between entity and identity of shop houses, based on analysis made on their facade design. Merely two cases of Klian Intan and Kuala Sepetang are contradictory to claim, in which the British did not make any adaptation of European style (rather more to Malay traditional features complemented with Chinese style). However, the majority of the localities have proven that entities involved in the construction of shop houses were influential towards the built identity, visible through the facade design.

On the other facet, the Malay identity has been found as the most prominent style displayed throughout the 16 localities. Indigenous materials, local climate and the existence of Malay traditional settlement existed earlier in time were among the contributing factors. The British meanwhile placed greater attention to major cities such as Ipoh, Taiping, Teluk Intan and Kuala Kangsar in relation to small townships. Hence, instead of shop houses, adaptation of European style can be found mostly at administrative buildings, officials' residences, schools, churches, railway stations etc.

\section{CONCLUSION}

The current study found there is a significant relationship in between the entity and identity of old shop houses in Perak by analysing their facade design. The Malay identity has been found to be the most prominent style for shop houses located in small towns of Perak. Complementing the Malay identity, it has also been found that the Chinese and European styles were also adapted to the facade design of shop houses at the localities studied. It is believed that more interpretations and conclusions on the architectural, economic and sociological aspects can be generated based on the data gathered. Further research can be conducted to advance the body of knowledge on architectural heritage by integrating variables important to the current study contexts such as climate, built 
Mohd Jaki Mamat ${ }^{1}$ \& Muhammad Firzan Abdul Aziz

The Entity - Identity Relationships of Old Shop Houses in Perak Through Facade Design

materials, construction skills and technology, construction costs, as well as, building functions and business types.

\section{ACKNOWLEDGEMENTS}

The author would like to express gratitude to Perak Town and Country Planning Department who had funded this study as well as other various parties contributing to the success of the current study especially Universiti Sains Malaysia, Ungku Omar Polytechnic, Perak Heritage Society and several individuals who were directly or indirectly involved.

\section{REFERENCES}

Aidatul Fadzlin Bakri, Nurulhusna Qamaruz Zaman, Hikmah Kamarudin, Nakiah Md Amin, (2014). Reviving the Physical and Cultural Attributes of Ethnic Enclave: A conservation approach, Procedia - Social and Behavioral Sciences 153, 341 348.

Andrew James Harding (2018). Five-foot ways as public and private domain in Singapore and beyond, Journal of Property, Planning and Environmental Law, Vol.10, No.1, pp. 36-55

Chee Siang Tan \& Kaori Fujita (2014). Building Construction of Pre-war Shophouses in George Town Observed Through a Renovation Case Study, Journal of Asian Architecture and Building Engineering, 13:1, 195-202.

Dheyaa Hussein, Somwrita Sarkar and Peter Armstrong (2018). Mapping preferences for the number of built elements, Smart and Sustainable Built Environment, Vol. 7, No. 1, pp. 53-67.

E. Wanda George (2010). Intangible cultural heritage, ownership, copyrights, and tourism, International Journal of Culture, Tourism and Hospitality Research, Volume: 4 Issue: 4.

Grant Samkin, Annika Schneider (2010). Accountability, narrative reporting and legitimation the case of a New Zealand public benefit entity, Accounting, Auditing \& Accountability Journal, Vol. 23 No. 2, pp. 256-289

Hideo Izumida (2003). A Study on British Architects in East and Southeast Asia: 1830 1940, Journal of Asian Architecture and Building Engineering, 2:2, b131-b136.

Lynn Hollen Lees (2017). Planting empire, cultivating subjects; British Malaya, 1786 1941, Cambridge University Press, United Kingdom.

Mohd Jaki Mamat \& Muhammad Firzan Abdul Aziz (2018). Early town planning system of small town in Perak, Planning Malaysia, Vol. 16, Issue 4, Page $55-67$.

Mohd Jaki Mamat, Rumah Melayu Tradisional Hulu Perak, Lembaga Muzium Negeri Perak, Ipoh.

Mostafa Sadeghifar, Mahdieh Pazhouhanfar and Mohammad Farrokhzad (2018). An exploration of the relationships between urban building façade visual elements and people's preferences in the city of Gorgan, Iran, Architectural Engineering and Design Management, DOI: 10.1080/17452007. 2018.1548340

N.A.M. Omar, S.F. Syed-Fadzil (2011). Assessment of Passive Thermal Performance for a Penang Heritage Shop house, Procedia Engineering 20, 203 - 212. 
Natthakit Phetsuriya (2017). Formal language of Lanna Shop House's Façade in Lampang Old city, Thailand, IOP Conf. Series: Materials Science and Engineering 245052015.

Nigel Taylor (2010). Commentary; what is this thing called spatial planning? An analysis of the British government's view, TPR, 81 (2).

Noorfadhilah Mohd Baroldin and Shamzani Affendy Mohd Din (2012). Documentation and Conservation Guidelines of Melaka Heritage Shophouses, Procedia - Social and Behavioral Sciences $50192-203$.

Norsidah Ujang (2012). Place Attachment and Continuity of Urban Place Identity, Procedia - Social and Behavioral Sciences 49, 156 - 167

Nur Farhana Azmi, Faizah Ahmad, Azlan Shah Ali (2014). Place Identity: A Theoretical Reflection, Open House International, Vol.39 No.4.

Nurlisa Gintinga, Julaihi Wahid (2015). Exploring Identity's Aspect of Continuity of Urban Heritage Tourism, Procedia - Social and Behavioral Sciences 202, 234 241.

Rashiwala, Kalpana (2018). Prime heritage play, The Business Times, Singapore, ProQuest 2034676637

Mohd Sabrizaa Abd. Rashid (2017). Rumah Kutai: Documentation of memories, Institut Darul Ridzuan, Ipoh.

Siti Norlizaiha Harun and Rusamah Abdul Jalil (2014). The History and Characteristics of Malay Early Towns in Peninsular Malaysia, Asian Journal of Humanities and Social Studies, Volume 02, Issue 03.

Shahrul Yani Said, Zalina Samadi (2016). The Evolution of Historic Streetscape in Adapting Modern Demand in Achieving the Quality of Life, Procedia - Social and Behavioral Sciences 234, pp 488 - 497.

S.N. Kamaruzzaman and R.E. Edwards (2006). Evaluating performance characteristics of electricity use of British historic buildings in Malaysia, Facilities, Vol. 24 No. 3/4, pp. 141-152.

Stephen Dobson (2012). Characterizing the evolution of commercial organizational spaces, International Journal of Organizational Analysis, Vol. 20, No. 3, pp. 309322.

Tan Yeow Wooi (2015). Penang Shophouses: A handbook of Features \& Materials, Tan Yeow Wooi \& Heritage Research Studio, Penang.

Umi Kalsum Zolkafli, Zahiriah Yahya, Norhanim Zakaria, Farid Wajdi Akashah and Azlan Shah Ali, (2015). Restoration of historical timber building: a Malaysian case study, Structural Survey Vol. 33 No. 4/5, pp. 309-321.

Yose Rizal, Rika Cheris \& Repi (2017). Approach of Urban Design Elements in Preservation Area Kampung Bandar Senapelan Towards Pekanbaru Metropolitan City, IOP Conf. Series: Earth and Environmental Science 97012022.

Wan Hashimah Wan Ismail (2015). Contemporary Uses of Buildings on a Heritage Street, Procedia - Social and Behavioral Sciences 170, 633 - 641.

Wang Han \& Dr. Jia Beisi (2016), Urban Morphology of Commercial Port Cities and Shophouses in Southeast Asia, Procedia Engineering 142, $190-197$.

Syed Zainol Abidin Idid (1995). Pemeliharaan Rupa Bandar: Panduan Mengenali Warisan Rupa Bandar berasaskan inventori bangunan warisan di Malaysia, Badan Warisan Malaysia, Kuala Lumpur. 
Mohd Jaki Mamat ${ }^{1}$ \& Muhammad Firzan Abdul Aziz

The Entity - Identity Relationships of Old Shop Houses in Perak Through Facade Design

Zulkefle Ayob, Siti Norlizaiha Harun (2012). The Legibility of Urban Square in Shaping City Image of Historical City in Peninsular Malaysia, Proceeding; Ist International Conference on Innovation and Technology for Sustainable Built Environment, page 911-917, Univeriti Teknologi MARA (Perak).

Received: January 2020. Accepted: $14^{\text {th }}$ May 2020 